\title{
Cross-reactivity between Parietaria judaica and Parietaria officinalis in immunotherapy extracts for the treatment of allergy to Parietaria
}

\author{
NATALY CANCELLIERE ${ }^{1}$, IRENE IGLESIAS ${ }^{2}$, ÁNGEL AYUGA ${ }^{1}$ and ERNESTO ENRIQUE MIRANDA ${ }^{2}$ \\ ${ }^{1}$ Medical Department, MERCK SLU, 28006 Madrid; ${ }^{2}$ Department of Allergology, Hospital of Sagunto, 46520 Valencia, Spain
}

Received July 11, 2019; Accepted January 2, 2020

DOI: $10.3892 /$ br.2020.1297

\begin{abstract}
Parietaria judaica and P. officinalis are the two most common subspecies of the Parietaria genus. $P$. judaica and $P$. officinalis have exhibited cross-reactivity in previous studies. $P$. judaica pollen is the main cause of allergy in the Mediterranean area. It has been shown that a high percentage of patients sensitized to $P$. judaica with allergic rhinitis (AR) have an increased risk of developing asthma. The present study aimed to confirm the cross-reactivity between $P$. judaica and $P$. officinalis and to evaluate the use of a single $P$. officinalis extract in patients allergic to both subspecies as a preferable option for the diagnosis and treatment of allergy in a highly pollinated area of the Spanish Mediterranean coast. The present study was a single centre, observational cross-sectional study of adult patients diagnosed with AR and/or bronchial asthma who were sensitized to Parietaria pollen. A total of 24 patients were enrolled in the study and included in the analysis. Allergovit ${ }^{\circledR}$ immunotherapy extracts were selected for the study based on the protein content ( $P$. officinalis pollen extract). The results of an in vitro ELISA revealed that $79.1 \%(n=19)$ of the patient sera were reactive to immunotherapy extracts. ELISA inhibition assay of the IgE binding to $P$. officinalis demonstrated inhibition values $>70 \%$ in the sera of highly reactive patients, confirming the cross-reactivity between the two Parietaria subspecies. In addition, all patients enrolled in the study exhibited double skin positivity against $P$. judaica and $P$. officinalis extracts, as assessed by the skin prick test, further supporting the in vivo reactivity between the two subspecies. The present study demonstrated that $P$. judaica and $P$. officinalis pollen extracts were highly cross-reactive, and that a unique $P$. officinalis pollen extract may be used for the diagnosis and immunotherapy of patients allergic to Parietaria.
\end{abstract}

Correspondence to: Dr Nataly Cancelliere, Medical Department, MERCK SLU, 40 Maria de Molina Street, 28006 Madrid, Spain E-mail: nataly.cancelliere@merckgroup.com

Key words: asthma, allergic rhinitis, Parietaria pollen, allergens, Parietaria judaica, Parietaria officinalis, immunotherapy, cross-reactivity

\section{Introduction}

Allergic rhinitis (AR) is a symptomatic disorder of the nose induced by an IgE-mediated inflammation following allergen exposure of the membranes lining the nose (1). Due to its increasing prevalence worldwide $(2,3)$, including up to $22 \%$ in Spain $(3,4)$, and the burden of symptoms impacting on the general well-being and health-related quality of life of patients suffering from this condition, AR represents a serious global health problem (5). AR and asthma frequently coexist, sharing a number of physiopathologic links and risk factors, including sensitization to allergens, total IgE levels and a family history of asthma (6). Between 20 and $50 \%$ of patients with AR have asthma $(6,7)$, and AR has been demonstrated to occur in $\leq 80 \%$ of patients with asthma (8). Previous studies have consequently questioned whether both diseases may represent different expressions of a same underlying genetic predisposition (9-13).

Parietaria is a genus of the wind-pollinated dicotyledonous weeds of the Urticaceae family, which is predominantly widespread in several areas of southern Europe (14). Parietaria includes several subspecies, of which $P$. judaica and $P$. officinalis are the most common. $P$. judaica grows mainly on the Mediterranean coasts of Spain, southern France, Italy and Greece, whereas $P$. officinalis can be more frequently located in northern Italy, central France and central and eastern Europe (14). $P$. judaica in the Mediterranean area has a very long pollination period, reaching peaks in the spring and autumn (15).

$P$. judaica pollen has been identified to be the main cause of allergy in the Mediterranean area (16). In a study conducted in Catalonia, Spain, $47.8 \%$ of patients with AR due to $P$. judaica also suffered from asthma (11). In addition, in a retrospective cohort study conducted in Italy, sensitization to $P$. judaica significantly increased the risk of developing asthma in patients with AR, whereas no associations for other types of pollens were identified (17).

The composition of the allergenic extracts of the $P$.judaica pollen has been extensively studied and molecularly cloned, and the two major allergens (Par j 1 and Par j 2) have been sequenced and characterized (18-21). Par j 1 and Par j 2 allergens are polypeptides of 14.7 and $11.3 \mathrm{kDa}$, respectively, that belong to the non-specific lipid transfer protein (20-22). The allergens share certain common structural similarities, as well as the same $\operatorname{IgE}$ binding epitopes (21). However, although the 
Par j 2 allergen has been recognized as the species-specific allergen marker of $P$. judaica sensitization (22), the full allergenic role and contribution of the two Pars have not been completely elucidated.

Resemblance and cross-reactivity of the two main subspecies of Parietaria, $P$. judaica and $P$. officinalis, have been confirmed in several studies (23-26). Bonura et al (25) demonstrated that the cross-reactivity between the two subspecies was due to the presence of the Par $\mathrm{j} 1$ and Par $\mathrm{j} 2$ allergens in the extracts with a high conserved IgE epitope content; all patients enrolled in their study exhibited a double-positive skin prick test (SPT) toward the P.judaica and P. officinalis extracts with similar IgE concentrations for both subspecies. In addition, ELISA inhibition experiments were performed to validate these results, thus demonstrating that the major $P$. judaica allergens inhibited most of the $P$. judaica- and $P$. officinalis-specific IgE in similar proportions (25). These results were confirmed in the study conducted by Patriarca et al (26), demonstrating that $P$. officinalis and $P$.judaica pollen extracts were completely cross-reactive. In addition, they revealed that one unique extract of $P$. officinalis was suitable for the in vivo diagnosis and immunotherapy of the patients allergic to Parietaria tested in the study (26).

Considering the above findings, the present study aimed to confirm that the use of a single $P$. officinalis extract in patients allergic to $P$. judaica and $P$. officinalis may be a suitable option for the diagnosis and treatment of patients sensitized to Parietaria in a high pollinated area of the Spanish Mediterranean coast.

\section{Materials and methods}

Study Design. It was a single centre, single visit, observational, cross-sectional study of adult patients diagnosed with AR and/or bronchial asthma sensitized to Parietaria pollen. The principal objective of the study was to assess the in vitro cross-reactivity between allergens present in $P$. judaica and P. officinalis. The secondary objective was to compare in vitro reactivities between $P$. judaica and $P$. officinalis in allergic patients sensitized to Parietaria.

Patients treated at the Hospital of Sagunto in a highly exposed to Parietaria pollen area of the Spanish Mediterranean coast (Levante) were included in the study from March to November 2017. Data were obtained either from the medical record or from a single visit that matched a routine consultation with a clinician, without interfering with the routine clinical practice. No therapeutic and/or diagnostic interventions were applied. Written informed consent was obtained from all study participants, and ethical approval was obtained from the Ethics Committee of Clinical Research at the Hospital of Sagunto (Valencia, Spain).

Patients. Patients eligible for this study had to fulfil all of the following inclusion criteria: i) Age, $\geq 18$ years; ii) diagnosed with AR and/or bronchial asthma and sensitized to $P$. judaica pollen; and iii) without any previous specific immunotherapy treatment for allergy to Parietaria. In addition, the patients underwent at least a 7-day period without of antihistamines and glucocorticoids prior to the study. The exclusion criteria were as follows: i) Patients with any clinical conditions preventing them from understanding the implications and requirements of the study; ii) patients polysensitized to profilins; and iii) patients under other simultaneous immunotherapy treatment during the study follow-up period.

Study variables. For the primary objective analysis, in vitro reactivity of patient sera (allergy-specific IgE levels) to immunotherapy extracts (P. officinalis) were determined by ELISA. Two different immunotherapy treatments were tested: $3 \mathrm{ml}$ $(10,000 \mathrm{UT} / \mathrm{ml})$ Allergovit ${ }^{\circledR}$ (Allergopharma; Merck KGaA) and $2.5 \mathrm{ml}(1,000 \mathrm{DPP} / \mathrm{ml})$ Depigoid $^{\circledR}$ (Laboratorios Leti, S.L.). Protein extracts of the immunotherapy products were obtained by incubation with $10 \mathrm{mM}$ PBS and $150 \mathrm{mM} \mathrm{NaCl}$ for $1 \mathrm{~h}$ at $4^{\circ} \mathrm{C}$. The supernatant was dialyzed against $\mathrm{H}_{2} \mathrm{O}$ and lyophilized. Subsequently, protein content was precipitated with $10 \%$ trichloroacetic acid, and the pellet was washed with cold acetone. The Bradford protein assay was used to quantify the protein content of the immunotherapy products.

ELISA. The reactivity of the sera was determined by ELISA assays produced in the laboratory of the Biotechnology and Plants Genomic Center at Polytechnic University of Madrid. Immunotherapy products were coated on ELISA plates at $50 \mu \mathrm{g} / \mathrm{ml}$ diluted in PBS for $2 \mathrm{~h}$ at $37^{\circ} \mathrm{C}$. Following blocking for $1 \mathrm{~h}$ at room temperature with blocking buffer (Sigma-Aldrich; Merck KGaA), the plates were washed with PBS-0.05\% Tween-20 and incubated with serum samples diluted 1:3 in PBS. The presence of the IgE was detected by incubation with horseradish peroxidase (HRP)-conjugated anti-IgE antibodies (1:3,000; cat. no. A9667; Sigma-Aldrich; Merck $\mathrm{KGaA}$ ) for $1 \mathrm{~h}$ at room temperature and revealed with OPD substrate (Thermo Fisher Scientific, Inc.). Optical density (OD) was measure at $450 \mathrm{~nm}$ in a microplate reader. OD values were counted as positive if they exceeded the mean OD of the negative controls by $>3$ standard deviations (i.e., values $>0.132$ ). Positive values corresponded to reactive sera, whereas negative values corresponded to sera that were not considered reactive. Subsequently, cross-reactivity between allergens from $P$. judaica and P. officinalis (Allergovit ${ }^{\circledR}$ ) pollen extracts was measured by the ELISA inhibition method.

ELISA inhibition. Sera of the patients exhibiting high reactivity to the sample (i.e. the highest OD values determined by the ELISA method) were selected for ELISA inhibition and were used as a reference of the index of stimulation of the sera without inhibition. The sera were inhibited by incubation with $30 \mu \mathrm{g}$ pollen protein extract from $P$. judaica. Immunotherapy protein extracts were coated on ELISA plates $(50 \mu \mathrm{g} / \mathrm{ml})$ and following blocking as described above, the plates were incubated with serum samples inhibited with pollen protein extract of $P$. judaica and developed with anti IgE-HRP antibodies and OPD subtract. ELISA experiments were performed at the Biotechnology and Plants Genomic Center at Polytechnic University of Madrid (Madrid, Spain).

To analyse the protein content of the extracts, the samples were analysed by SDS-PAGE and Coomassie staining. Briefly, SDS-PAGE was performed using a $15 \%$ polyacrylamide gel and $0.1 \%$ SDS under reducing conditions with 2-mercaptoethanol. Proteins were visualised by staining with $0.25 \%$ Brilliant blue R250 (cat. no. B0149' Sigma-Aldrich; Merck KGaA), 9\% 
Table I. Clinical characteristics of all patients enrolled in the present study.

\begin{tabular}{|c|c|c|c|c|}
\hline Patient no. & $\begin{array}{c}\text { Bronchial } \\
\text { asthma diagnosis }\end{array}$ & Atopy & $\begin{array}{l}\text { SPT: } P . \text { judaica } \\
(\mathrm{D}+\mathrm{d}) / 2, \mathrm{~mm}\end{array}$ & $\begin{array}{l}\text { SPT: P. officinalis } \\
\quad(\mathrm{D}+\mathrm{d}) / 2, \mathrm{~mm}\end{array}$ \\
\hline 1 & No & Yes & 8.00 & 6.50 \\
\hline 2 & Yes & Yes & 14.00 & 13.50 \\
\hline 3 & Yes & Yes & 10.00 & 11.00 \\
\hline 4 & No & Yes & 8.50 & 7.50 \\
\hline 5 & No & Yes & 16.00 & 10.00 \\
\hline 6 & No & Yes & 8.50 & 8.50 \\
\hline 7 & No & Yes & 10.00 & 9.00 \\
\hline 8 & Yes & Yes & 7.00 & 6.50 \\
\hline 9 & No & Yes & 13.50 & 12.00 \\
\hline 10 & Yes & Yes & 10.00 & 7.00 \\
\hline 11 & Yes & Yes & 6.50 & 7.50 \\
\hline 12 & Yes & Yes & 11.00 & 10.50 \\
\hline 13 & No & Yes & 8.50 & 9.50 \\
\hline 14 & Yes & Yes & 10.00 & 9.50 \\
\hline 15 & No & Yes & 4.50 & 4.00 \\
\hline 16 & No & Yes & 10.00 & 8.00 \\
\hline 17 & No & Yes & 10.00 & 9.50 \\
\hline 18 & No & Yes & 8.50 & 5.00 \\
\hline 19 & Yes & Yes & 7.50 & 7.00 \\
\hline 20 & No & Yes & 13.50 & 8.50 \\
\hline 21 & Yes & Yes & 11.50 & 9.00 \\
\hline 22 & No & Yes & 12.00 & 11.00 \\
\hline 23 & No & Yes & 12.00 & 9.00 \\
\hline 24 & Yes & Yes & 7.50 & 8.50 \\
\hline
\end{tabular}

SPT, skin prick test; $P$., Parietaria; D, longest wheal diameter; $\mathrm{d}$, longest diameter perpendicular to D.

acetic acid and $50 \%$ methanol by agitation on a shaker for $30 \mathrm{~min}$ at room temperature. Coomassie brilliant blue staining was removed using a destaining solution (40\% methanol and $7 \%$ acetic acid) with gentle agitation at room temperature until the protein bands were visible.

For the secondary objective analysis, a SPT was performed to compare the in vivo reactivities between the two Parietaria subspecies in allergic patients sensitized to Parietaria by evaluating the specific mean IgE levels to $P$. judaica and $P$. officinalis and the total mean IgE levels obtained either from the patient medical records or a regular visit to the clinician. In addition, associations between the variables measured by the SPT for $P$. judaica and $P$. officinalis were analysed. Patients underwent SPT with $P$. judaica (ALK-Abelló ${ }^{\circledast}$ ) and $P$. officinalis (Allergopharma ${ }^{\circledR}$ ) aeroallergen plus a positive and negative control placed on the skin $\geq 2 \mathrm{~cm}$ apart. The positive control was $10 \mathrm{mg} / \mathrm{ml}$ histamine dichloride, and the negative control was glycerinated saline histamine at the same concentration. Test reading was performed at $15 \mathrm{~min}$.

Statistical analysis. Statistical analyses were performed using SPSS version 22.0 (IBM Corp.). Sample size was calculated based on the necessary number of patients to achieve the primary objective (in vitro cross-reactivity between allergens present in P. judaica and P.officinalis). The sample size of the present study was calculated based on the results of a previous study that identified a significant correlation $(\mathrm{r}=0.98 ; \mathrm{P}<0.0001)$ between patient sera specific IgE levels for $P$. judaica and $P$. officinalis with a sample of 30 patients (26).

For the overall descriptive analysis, quantitative variables were presented as the mean \pm SD or median with first quartile (Q1), third quartile (Q3), minimum and maximum. Qualitative variables were described with absolute and relative frequencies with the valid percentages (percentages that do not include missing data) and total percentages (the sum of the valid responses plus the missing values). In cases where these two percentages had different values, the valid percentage was reported. Absent data were left as missing values.

Bivariate analyses with the parametric paired-sample t-test were performed to assess the secondary objective, assuming a normal distribution of the sample continuous variables. The $95 \%$ confidence intervals (CI) were estimated when required. $\mathrm{P}<0.05$ was considered to indicate a statistically significant difference.

\section{Results}

Patients. A total of 24 patients meeting all the inclusion criteria entered the study and were included in the analysis. The mean 
Table II. SPT of in vivo reactivities between two Parietaria subspecies in allergic patients sensitised to Parietaria.

\begin{tabular}{|c|c|c|c|c|c|c|c|c|}
\hline SPT result & Mean $(95 \% \mathrm{CI})$ & SD & Median & Minimum & Maximum & Q1 & Q3 & $\mathrm{N}$ \\
\hline \multicolumn{9}{|c|}{ Positive control (histamine) } \\
\hline $\mathrm{D}, \mathrm{mm}$ & $8.8(7.8-9.8)$ & 2.4 & 8.0 & 5.0 & 17.0 & 7.3 & 10.0 & 24 \\
\hline $\mathrm{d}, \mathrm{mm}$ & $6.5(5.8-7.1)$ & 1.5 & 6.0 & 4.0 & 1 & 5.0 & 7.8 & 24 \\
\hline$(\mathrm{D}+\mathrm{d}) / 2, \mathrm{~mm}$ & $7.7(7.0-7.1)$ & 1.7 & 7.0 & 5.0 & 12.5 & 6.6 & 9.0 & 24 \\
\hline \multicolumn{9}{|l|}{ Negative control } \\
\hline $\mathrm{D}, \mathrm{mm}$ & $0.0(-)$ & 0.0 & 0.0 & 0.0 & 0.0 & 0.0 & 0.0 & 24 \\
\hline $\mathrm{d}, \mathrm{mm}$ & $0.0(-)$ & 0.0 & 0.0 & 0.0 & 0.0 & 0.0 & 0.0 & 24 \\
\hline$(\mathrm{D}+\mathrm{d}) / 2, \mathrm{~mm}$ & $0.0(-)$ & 0.0 & 0.0 & 0.0 & 0.0 & 0.0 & 0.0 & 24 \\
\hline \multicolumn{9}{|c|}{ Parietaria Judaica } \\
\hline $\mathrm{D}, \mathrm{mm}$ & $11.8^{\mathrm{a}}(10.4-13.3)$ & 3.4 & 11.0 & 5.0 & 19.0 & 10.0 & 15.0 & 24 \\
\hline $\mathrm{d}, \mathrm{mm}$ & $7.6^{\mathrm{a}}(6.7-8.4)$ & 2.0 & 7.0 & 4.0 & 12.0 & 6.3 & 9.0 & 24 \\
\hline$(\mathrm{D}+\mathrm{d}) / 2, \mathrm{~mm}$ & $10.0^{\mathrm{a}}(8.8-11.1)$ & 2.7 & 10.0 & 4.5 & 16.0 & 8.1 & 11.9 & 24 \\
\hline \multicolumn{9}{|c|}{ Parietaria officinalis } \\
\hline $\mathrm{D}, \mathrm{mm}$ & $10.4(9.1-11.7)$ & 3.1 & 10.0 & 5.0 & 18.0 & 9.0 & 12.0 & 24 \\
\hline $\mathrm{d}, \mathrm{mm}$ & $7.0(6.2-7.7)$ & 1.8 & 6.0 & 3.0 & 10.0 & 6.0 & 8.8 & 24 \\
\hline$(\mathrm{D}+\mathrm{d}) / 2, \mathrm{~mm}$ & $8.7(7.8-9.6)$ & 2.2 & 8.8 & 4.0 & 13.5 & 7.1 & 9.9 & 24 \\
\hline
\end{tabular}

${ }^{\mathrm{a}} \mathrm{P}<0.05$ vs. Parietaria officinalis. SPT, skin prick test; Q1, first quartile; Q3, third quartile; D, longest wheal diameter; d, longest diameter perpendicular to D.

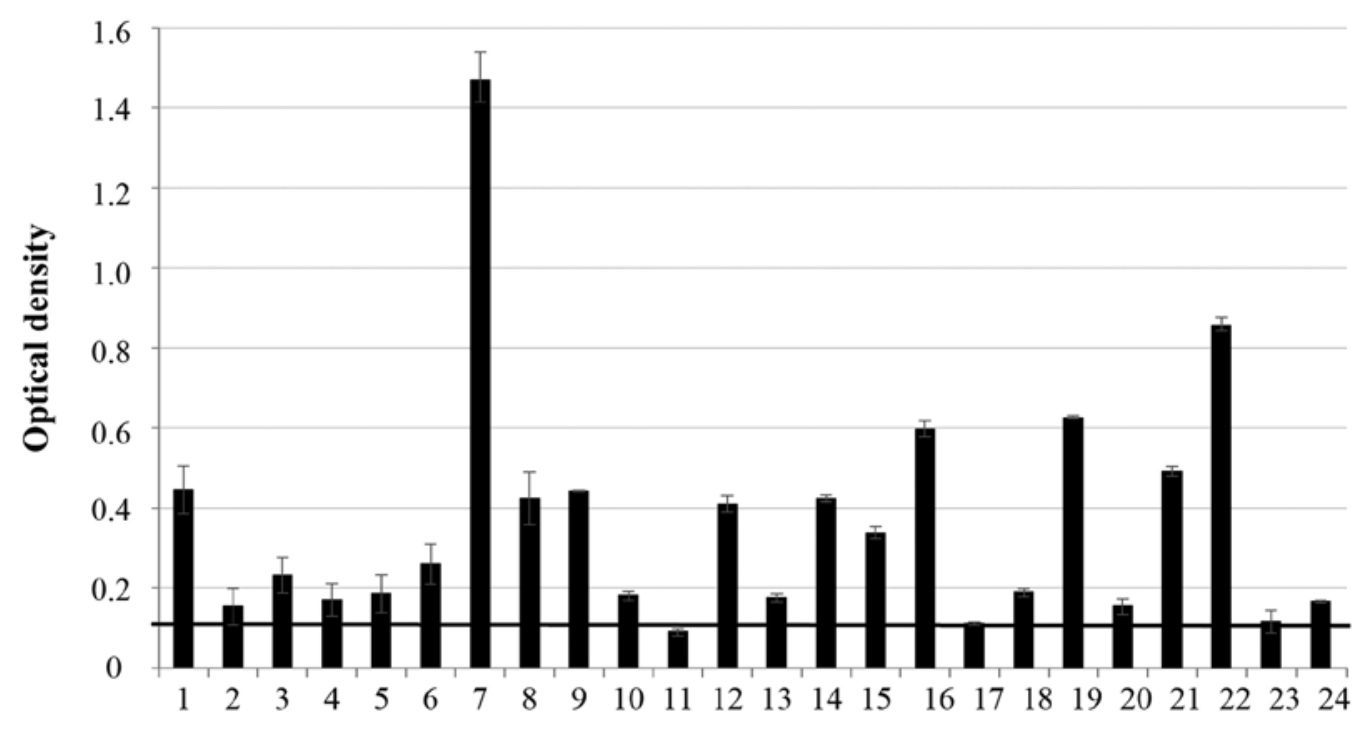

Patient serum

Figure 1. ELISA reactivity to Parietaria extract (Allergovit ${ }^{\circledR}$ ) in all patients. The graph represents the ELISA reactivity when the SD of each sample was not considered.

age of the participants was 40 years (range, 26-67 years), and $37.5 \%$ of the patients were female. All patients suffered from AR and $41.7 \%(n=10)$ were diagnosed with bronchial asthma. None of the patients presented comorbidities, such as diabetes or arterial hypertension, and 22.7 and $25 \%$ were regarded as current smokers or daily alcohol drinkers, respectively. Table I displays the clinical characteristics of each patient included in the study.

In vitro cross-reactivity between allergens present in $P$. judaica and $P$. officinalis. The Bradford protein test revealed that
Allergovit ${ }^{\circledR}$ had a protein content of $0.5 \mu \mathrm{g} / \mu \mathrm{l}$, whereas Depigoid ${ }^{\circledR}$ had a protein content of $0.05 \mu \mathrm{g} / \mu \mathrm{l}$. The protein content in Allergovit ${ }^{\circledR}$ (mainly from $P$. officinalis extracts) and the absence of protein content in Depigoid ${ }^{\circledR}$ was confirmed by electrophoresis under denatured conditions and Coomassie staining.

The in vitro ELISA method performed in high-binding 96-well plates coated with Allergovit ${ }^{\circledR}$ demonstrated that $87.5 \%(n=21)$ of the patient sera were reactive (i.e. exhibited high levels of specific IgE to P.officinalis) when the SD of each sample was not considered (Fig. 1), and $79.1 \%(n=19)$ of the 


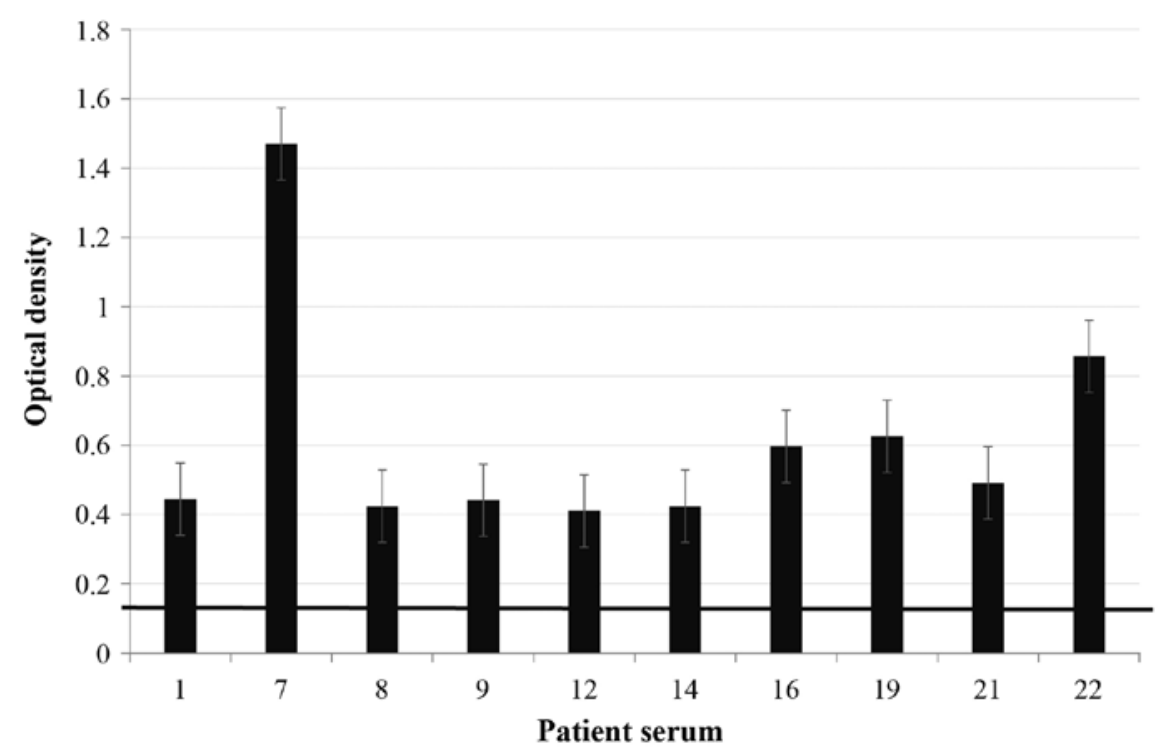

Figure 2. ELISA reactivity to Parietaria extract (Allergovit ${ }^{\circledR}$ ). The graph represents ELISA reactivity of the 10 patients with the highest reactivity to the sample.

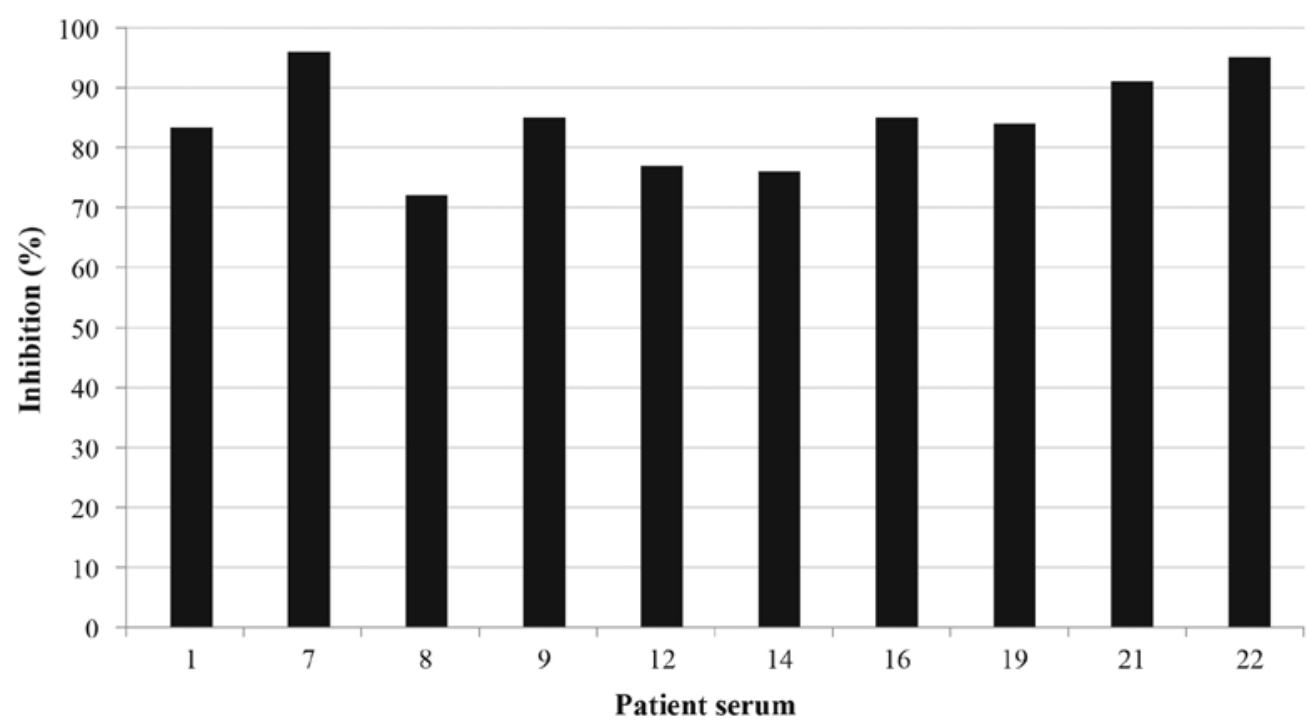

Figure 3. ELISA inhibition assay of the IgE binding to Parietaria officinalis. Exhibited inhibition values were $>70 \%$ in serum from the 10 patients with the highest reactivity to the sample.

patient sera were reactive when the OD value (minus SD) was above the threshold of 0.132 (data not shown). High specific $\mathrm{IgE}$ ranged between 0.091 and $1.47 \mathrm{OD}$ when the SD of each sample was not considered and between 0.082 and 1.407 OD when SD was included. No reaction in the patient sera was observed when the ELISA plates were coated with Depigoid ${ }^{\circledR}$.

Sera of the 10 patients $(1,7,8,9,12,14,16,19,21$ and 22) with the highest reactivity to the sample (i.e. highest OD values identified by the ELISA) (Fig. 2) were selected to test cross-reactivity between allergens from $P$. judaica and $P$. officinalis by ELISA inhibition and were also used as a reference of the index of stimulation of the sera without inhibition. ELISA inhibition assay of the IgE binding to P. officinalis exhibited inhibition values $>70 \%$ (ranging between 71.76 and $95.97 \%$ ) in the sera of the 10 patients (Fig. 3), confirming cross-reactivity between the two Parietaria subspecies.
Comparison of in vivo reactivities between two Parietaria subspecies in allergic patients sensitized to Parietaria. All patients enrolled in the study exhibited double skin positivity against $P$. judaica and $P$. officinalis extracts, as assessed by the SPT (Table II). A parametric paired-sample Student's t-test identified greater wheal sizes for $P$. judaica compared with those for $P$. officinalis when measured by the longest wheal diameter $(\mathrm{D}$; mean $\pm \mathrm{SD}, 11.8 \pm 3.4 \mathrm{~mm}$ for $P$. judaica and $10.4 \pm 3.1 \mathrm{~mm}$ for $P$. officinalis; $\mathrm{P}=0.030$ ), the longest diameters perpendicular to $\mathrm{D}(\mathrm{d}$; mean $\pm \mathrm{SD}, 7.6 \pm 2 \mathrm{~mm}$ for $P$. judaica and $7 \pm 1.8 \mathrm{~mm}$ for $P$. officinalis; $\mathrm{P}=0.036)$ and $(\mathrm{D}+\mathrm{d}) / 2($ mean $\pm \mathrm{SD}$, $10 \pm 2.7 \mathrm{~mm}$ for $P$. judaica and $8.7 \pm 2.2 \mathrm{~mm}$ for $P$. officinalis; $\mathrm{P}=0.002$ ). Positive skin reactivity was also observed for the positive control (histamine) with a mean \pm SD of $8.8 \pm 2.4 \mathrm{~mm}$ for $\mathrm{D}, 6.5 \pm 1.5 \mathrm{~mm}$ for $\mathrm{d}$ and $7.7 \pm 1.7 \mathrm{~mm}$ for $(\mathrm{D}+\mathrm{d}) / 2$. The negative control exhibited negative reactions in all patients. 
Differences between the levels of IgE specific to $P$. judaica and $P$. officinalis could not be assessed as specific IgE levels to $P$. officinalis were not available.

\section{Discussion}

The identification and characterization of cross-reactive allergens provides clinicians with useful and practical guidance to optimize and improve diagnosis and immunotherapy treatment for patients with AR. The present study was conducted with the objective of assessing the cross-reactivity between two subspecies of the genus Parietaria, P. judaica and $P$. officinalis, in a sample of 24 patients diagnosed with AR and/or bronchial asthma due to Parietaria pollen, from the Levante region of the Spanish Mediterranean coast. For this purpose, immunotherapy extracts for the treatment of allergy to Parietaria (Allergovit ${ }^{\circledR}$ containing P. officinalis) were used. The final sample of patients was lower compared with the initially calculated number (30 patients); however, Bonura et al (25) had previously identified cross-reactivity between the two Parietaria subspecies by using the $\operatorname{rPar} \mathrm{j} 1$ and $\mathrm{rPar} \mathrm{j} 2$ allergens in a sample of 25 patients.

The Bradford protein test confirmed that Allergovit ${ }^{\circledR}$, in contrast to Depigoid ${ }^{\circledR}$, contained proteins of P. officinalis extracts; it is widely known that a high variability exists in extracts of the same allergenic grass species produced by different companies, both qualitatively and quantitatively (27).

The results of the SPT in the present study revealed that all patients primarily sensitized to $P$. judaica pollen, as evidenced by significant skin reactivity and detected specific IgE levels, also exhibited significant reactivity to $P$. officinalis pollen. The in vitro ELISA test demonstrated that $87.5 \%$ of the patients were reactive to $P$. officinalis pollen, as confirmed by an OD ratio between 0.091 and 1.47, when the SD of the samples was not regarded; $79.1 \%$ of the patients still exhibited a significant OD ratio, between 0.082 and 1.407, when the $\mathrm{SD}$ of the individual samples was considered. In addition, 10 selected patients with the highest reactivity to the pollen extract (Allergovit ${ }^{\circledR}$ ) exhibited ELISA inhibition values of $\operatorname{IgE}$ binding to $P$. officinalis $>70 \%$, confirming the cross-reactivity between the two Parietaria subspecies. Additionally, 2 patients reached values $>95 \%$. ELISA inhibition method instead of a direct binding test was selected in our study for the cross-reactive assessment of polyclonal antibodies, as this method is considered to be more reliable and to better discriminate between cross-reacting and non-cross-reacting $\operatorname{IgE}$ levels (28).

These results are comparable to the findings obtained by Patriarca et al (26) in a sample of 30 Italian patients allergic to Parietaria pollen, and provide further evidence to confirm the complete cross-reactivity of $P$. officinalis and $P$. judaica extracts, as well as support the use of $P$. officinalis pollen extract in the diagnosis and immunotherapy of Parietaria allergy. In addition, compared with other cross-reactivity assessment studies, such as those associated with sensitization to pollen and vegetable foods presented by Aalberse (29) in their review, the results of the present study yielded higher cross-reactivity values.

The present study had certain limitations inherent to its retrospective design. Only patient data from the medical records as part of their routine medical care were collected, and total IgE levels, as well as specific IgE levels for $P$. judaica, were thus only available for a limited number of patients. In addition, quantification assays performed for detecting the levels of IgE specific for P. judaica and P. officinalis were not comparable, as they used different methods and detection ranges.

Another limitation was the use of a single Parietaria antigen concentration for the $\operatorname{IgE}$ binding inhibition assay to determine the subspecies cross-reactivity, as it was not possible to test inhibition of IgE binding variations using pollen proteins at different concentrations.

Finally, the results of the present study can only be generalized to the population of patients allergic to Parietaria from the Spanish Levante Coast area. Further similar studies implemented in other geographical zones should be conducted to verify these results.

In conclusion, the present study demonstrated that $P$. judaica and $P$. officinalis pollen extracts were highly cross-reactive, and that a unique $P$. officinalis pollen extract (Allergovit ${ }^{\circledR}$ ) may be used for the diagnosis and immunotherapy of patients allergic to Parietaria.

\section{Acknowledgements}

Not applicable.

\section{Funding}

This study was funded by MERCK SLU.

\section{Availably of data materials}

The datasets used or analysed during the current study are available from the corresponding author on reasonable request.

\section{Authors' contributions}

NC, II, AA and EEM substantially contributed to the acquisition, analysis and interpretation of data, drafted the manuscript, critically revised the manuscript for important intellectual content, and gave final approval of the version to be published. All authors have read and approved the final manuscript.

\section{Ethics approval and consent to participate}

Written informed consent was obtained from all study participants and ethics approval for this study was obtained from the Ethics Committee of Clinical Research at Hospital of Sagunto (Valencia, Spain).

\section{Patient consent for publication}

Not applicable.

\section{Competing interests}

Nataly Cancelliere and Ángel Ayuga are employees of MERCK SLU. The other the authors declare that they have no competing interests. 


\section{References}

1. Bousquet J, Van Cauwenberge P and Khaltaev N; Aria Workshop Group, World Health Organization: Allergic rhinitis and its impact on asthma. J Allergy Clin Immunol 108 (Suppl 5): S147-S334, 2001.

2. Bousquet J, Khaltaev N, Cruz AA, Denburg J, Fokkens WJ, Togias A, Zuberbier T, Baena-Cagnani CE, Canonica GW, van Weel C, et al: Allergic rhinitis and its impact on asthma (ARIA) 2008 update (in collaboration with the World Health Organization, GA(2)LEN and AllerGen). Allergy 63 (Suppl 86): S8-S160, 2008

3. Bauchau V and Durham SR: Prevalence and rate of diagnosis of allergic rhinitis in Europe. Eur Respir J 24: 758-764, 2004.

4. Mullol J, Valero A, Alobid I, Bartra J, Navarro AM, Chivato T, Khaltaev $\mathrm{N}$ and Bousquet $\mathrm{J}$ : Allergic rhinitis and its impact on asthma update (ARIA 2008). The perspective from Spain. J Investig Allergol Clin Immunol 18: 327-334, 2008.

5. Canonica GW, Bousquet J, Mullol J, Scadding GK and Virchow JC: A survey of the burden of allergic rhinitis in Europe. Allergy 62 (Suppl 85): S17-S25, 2007.

6. Bousquet J, Vignola AM and Demoly P: Links between rhinitis and asthma. Allergy 58: 691-706, 2003.

7. Pereira C, Valero A, Loureiro C, Dávila I, Martinez-Cócera C, Murio C, Rico P and Palomino R: Iberian study of aeroallergens sensitisation in allergic rhinitis. Eur Ann Allergy Clin Immunol 38: 186-194, 2006.

8. Navarro A, Valero A, Julià B and Quirce S: Coexistence of Asthma and Allergic Rhinitis in Adult Patients Attending Allergy Clinics: ONEAIR Study. J Investig Allergol Clin Immunol 18: 233-238, 2008

9. Leynaert B, Neukirch C, Kony S, Guénégou A, Bousquet J, Aubier M and Neukirch F: Association between asthma and rhinitis according to a topic sensitization in a population-based study. J Allergy Clin Immunol 113: 86-93, 2004.

10. Kanani AS, Broder I, Greene JM and Tarlo SM: Correlation between nasal symptoms and asthma severity in patients with atopic and nonatopic asthma. Ann Allergy Asthma Immunol 94: 341-347, 2005.

11. Sala-Cunill A, Bartra J, Dalmau G, Tella R, Botey E, Raga E and Valero A; Comitè de Allergia Respiratòria de Catalunya, Spain: Prevalence of asthma and severity of allergic rhinitis comparing 2 perennial allergens: House dust mites and Parietaria judaica pollen. J Investig Allergol Clin Immunol 23: 145-151, 2013.

12. Passalacqua G and Canonica GW: Impact of rhinitis on airway inflammation: Biological and therapeutic implications. Respir Res 2: 320-323, 2001.

13. de Benedictis FM, del Guidice MM, Severine S and Bonifazi F: Rhinitis, sinusitis and asthma: One linked airway disease. Pediatr Respir Rev 2: 358-364, 2001.

14. D'Amato G, Cecchi L, Bonini S, Nunes C, Annesi-Maessano I, Behrehdt $\mathrm{H}$, Liccardi G, Popov T and van Cauwenberge $\mathrm{P}$ Allergenic pollen and pollen allergy in Europe. Allergy 62: 976-990, 2007.
15. Ariano R, Cecchi L, Voltolini S, Quercia O, Scopano E and Ciprandi G; AAIITO Study group on Pollen Allergy: Parietaria pollination duration: Myth or fact? Eur Ann Allergy Clin Immunol 49: 6-10, 2017.

16. Colombo P, Duro G, Costa MA, Izzo V, Mirisola M, Locorotondo G, Cocchiara R and Geraci D: An update on allergens. Parietaria pollen allergens. Allergy 53: 917-921, 1998.

17. Polosa R, Al-Delaimy WK, Russo C, Piccillo G and Sarvà M: Greater risk of incident asthma cases in adults with allergic rhinitis and effect of allergen immunotherapy: A retrospective cohort study. Respir Res 6: 153, 2005.

18. Geraci D, Billesbolle KB, Cocchiara R, Løwenstein H and Ipsen H: Immunochemical characterization of antigens of Parietaria judaica pollen. Identification of allergens by means of crossed radio immunoelectrophoresis. Int Arch Allergy Appl Immunol 78: 421-428, 1985.

19. Ford SA, Baldo BA, Geraci D and Bass D: Identification of Parietaria judaica pollen allergens. Int Arch Allergy Appl Immunol 79: 120-126, 1986.

20. Costa MA, Colombo P, Izzo V, Kennedy H, Venturella S, Cocchiara R, Mistrello G, Falagiani P and Geraci D: cDNA cloning, expression and primary structure of Par jI, a major allergen of Parietaria judaica pollen. FEBS Lett 341: 182-186, 1994.

21. Duro G, Colombo P, Assunta Costa M, Izzo V, Porcasi R, Di Fiore R, Locorotondo G, Cocchiara R and Geraci D: Isolation and characterization of two cDNA clones coding for isoforms of the Parietaria judaica major allergen Par j 1.0101. Int. Arch. Allergy Appl Immunol 112: 348-355, 1997.

22. Longo V, Costa MA, Cibella F, Cuttitta G, La Grutta S and Colombo P: Multiple IgE recognition on the major allergen of the Parietaria pollen Par j 2. Mol Immunol 63: 412-419, 2015.

23. Corbi AL, Pelaez A, Errigo E and Carreira J: Cross-reactivity between Parietaria judaica and Parietaria officinalis. Ann Allergy 54: 142-147, 1985.

24. Dreborg S, Basomba A and Einarsson R: Sensitivity to Parietaria officinalis and Parietaria judaica pollen allergens in a Spanish population. Allergol Immunopathol (Madr) 14: 499-508, 1986.

25. Bonura A, Artale A, Marino M, Amoroso S, Marcucci F, Geraci D and Colombo P: Cross-reactivity between Parietaria species using the major rParj1 and rParj2 allergens. Allergy Asthma Proc 27: 378-382, 2006.

26. Patriarca G, Marino G, De Pasquale T, Broutin O, Viatte A, Jain K, Hrabina M, Gouyon B, Moingeon P, Frati F, et al: Parietaria officinalis pollen extract can replace Parietaria judaica in the diagnosis and immunotherapy of Parietaria allergy. Allergy 65 (Suppl 92): S209-S682, 2010.

27. Sander I, Fleischer $C$, Meurer $U$, Brüning $T$ and Raulf-Heimsoth M: Allergen content of grass pollen preparations for skin prick testing and sublingual immunotherapy. Allergy 64: 1486-1492, 2009.

28. Aalberse RC: Assessment of allergen cross-reactivity. Clin Mol Allergy 5: 2, 2007.

29. Aalberse RC, Akkerdaas J and van Ree R: Cross-reactivity of IgE antibodies to allergens. Allergy 56: 478-490, 2001. 